\title{
Evaluation of Subchronic Formaldehyde Exposure in Rats with Open Field Test
}

\author{
Evaluación de la Exposición al Formaldehído Subcrónico \\ en Ratas con Prueba de Campo Abierto
}

Rabia Tasdemir ${ }^{v} \&$ Tuncay Colak $^{2}$

\begin{abstract}
TASDEMIR, R. \& COLAK, T. Evaluation of subchronic formaldehyde exposure in rats with open field test. Int. J. Morphol., 39(6):17581762, 2021.

SUMMARY: Formaldehyde (FA), which is an indispensable chemical substance in anatomy and pathology, is a very harmful substance for living things. In our study, the purpose was to investigate the changes in behavior of rats exposed to subchronic formaldehyde with open field test. We divided 24 Wistar-Albino rats into 3 groups. The first group $(n=8)$ was identified as the control group, and normal air breathing was ensured. Low-dose FA (mean 1 ppm) was inhaled in the second group, and high-dose FA (mean 10 ppm) was inhaled in the third group. FA exposure was done for 4 hours, 12 weeks, and 5 days a week. The rats were subjected to open field test during the first week and the last week of FA exposure. We observed significant decreases in the number of vertical movements and grooming in rats in the experimental group compared to the control group in the open field test $(\mathrm{p}<0.05)$. We did not detect any significant differences in horizontal movements and defecation counts $(\mathrm{p}>0.05)$. As a conclusion, we can argue that FA causes changes in the behaviors of rats regardless of dose and duration.
\end{abstract}

KEY WORDS: Formaldehyde exposure; Open field test; Rat.

\section{INTRODUCTION}

Formaldehyde (FA) is a toxic chemical and is used widely in industry as well as in medicine. There are studies reporting that FA, which harms almost all systems, from the heart to the kidneys, also affects the nervous system negatively, along with behaviors and memory in studies conducted in humans and experimental animals (Malek et al., 2004; Ge et al., 2019; Li et al., 2020; Acar et al., 2021; Zhang et al., 2021). Rats were exposed to open field test in previous studies by applying FA intraperitoneally or acutely, and decreases were found in locomotor activity (Boja et al., 1985; Malek et al., 2003a,b).

The open field test is one of the most preferred tests to detect changes, which may occur after applications in experimental animals (Küçük \& Gölgeli, 2005). It is also used to detect emotions, locomotor activity and sedation because of anxiety (Küçük \& Gölgeli). Two factors trigger the anxiety behaviors of animals in open areas: the animal being taken from its own environment and leaving it alone in an unfamiliar environment and the fear of wide areas as the open and wide environment is a problem for rodents (Prut \& Belzung, 2003). The time the animal was left in open area in the test ranged from 2 to 20 minutes during which the animal's movements in horizontal plane (transition from one frame to the next), movements in vertical plane (rising on hind limbs), grooming and the number of stools were identified. Locomotion is directly proportional to the number of horizontal movements, and the behavior of exploring the environment is directly proportional to the number of vertical movements. The number of grooming and defecation are taken as indicators of autonomous functions (Küçük \& Gölgeli).

There are studies reporting that the effects of formaldehyde vary depending on the dose and time (Liu et al., 2009). Unlike previous studies, the purpose of our study was to investigate whether locomotor activity would change depending on the dose and exposure times by exposing rats to subchronic formaldehyde.

\footnotetext{
${ }^{1}$ Department of Anatomy, Faculty of Medicine, Gaziantep Islam Science and Tecnology University, Gaziantep, Turkey.

${ }^{2}$ Department of Anatomy, Faculty of Medicine, Kocaeli University, Kocaeli, Turkey.
} 


\section{MATERIAL AND METHOD}

The study was commenced after the approval of Kocaeli University Animal Experiments Local Ethics Committee was obtained on 20.10.2016 with the number 6/ $1-2016$.

Animals: A total of 24 6-month-old female Wistar albino rats (Katsnelson et al., 2013) were obtained for the study from Kocaeli University Experimental Medicine Research and Application Unit. The rats were allowed to live freely in their own cages in 12 hours light and 12 hours darkness. The temperature of the cages was $20^{\circ} \mathrm{C}$ on average and the humidity was between $20-40 \%$ on average. They were fed with normal pellet feed and drinking water. The mean weight of the rats before the experiment was measured to be $254.42 \pm 13.25 \mathrm{~g}$. The rats were measured every week on the same day at the same time during the 12-week period, Tails of animals were stained with a different color after each weight measurement to avoid confusion. Their physical activities and appearance were monitored continuously with the FA exposure.

The rats were selected randomly, and divided into 3 groups. The first group was identified as the control group (n: 8) (CG) and normal air breathing was ensured. The second group (n:8) (LDG) was exposed to an average of $1 \mathrm{ppm}$ low dose FA for 12 weeks, 5 days a week, 4 hours daily. The third group (n: 8) (HDG) was also exposed to an average of 10ppm high-dose FA (Katsnelson et al.).

We ensured subchronic FA exposure to rats in our experiment in line with the "OECD Guideline for the Testing of Chemicals published in Organization for Economic Cooperation and Development (OECD, 2009).

Experimental setup: A glass cabinet of $100 \mathrm{~cm} * 70 \mathrm{~cm} * 35 \mathrm{~cm}$ was used in our study. The interior of the cabin was separated by a glass part, $20 \mathrm{~cm} \times 80 \mathrm{~cm}$. A hole with a diameter of 6 $\mathrm{cm}$ was drilled to allow air passage, and a hole with a diameter of $6 \mathrm{~cm}$ was made in the glass wall of the outer wall of the large compartment, and the FA-dense air in the cabin was discharged with a plastic pipe attached. A cover that could be opened from the top was made for the compartments in the cabin. In this way, the experimental animals were placed in the cabin (Matsuoka et al., 2010) (Fig. 1). Trials were done in an empty cage for one week to optimize the amount of formaldehyde and to test the usability of the device and cabinet, to provide low dose FA exposure, 2 drops FA were dropped on the napkin in the small section, and 9 drops FA was dropped on the napkin to provide high dose FA exposure. Honeywell ToxiRAE PRO (HCHO) dosimeter was placed in the large compartment to monitor the rats and the amount of FA in the cabin. We monitored the amount of FA recorded during the experiment from the computer by uploading the program of the dosimeter to the computer, and evaluated whether we created low-dose and high-dose FA on average objectively. We also calibrated the dosimeter every day before starting the experiment In order for the FA measurements to be reliable.

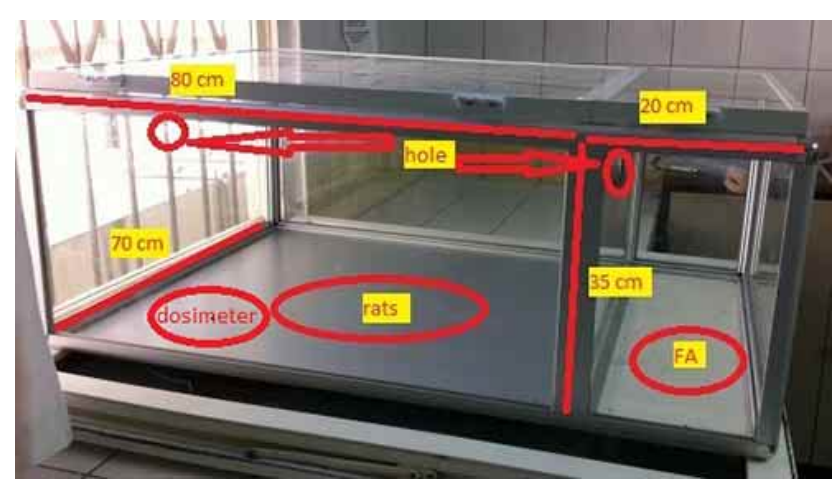

Fig. 1. Cabinet used for experimentation. The FA vapor in the small compartment passes through the $6 \mathrm{~cm}$ diameter hole in between to the part where the rats are located. The FA concentration is measured by the dosimeter in the section where the rats are located.

Open field test: A computerized animal activity monitoring system (Commat Ltd., Turkey) that had Plexiglas chamber was used to evaluate locomotor activity (LA) of rats in the morning and during the first and last week of FA exposure repeatedly with an open field activity software package. The Plexiglas chamber $(40 \times 40 \times 35 \mathrm{~cm})$ had a pair of infrared photo beams and detectors mounted vertically at every 4.5 $\mathrm{cm}$ and horizontally at every $2.5 \mathrm{~cm}$. The software program was used to detect and record the interruptions of photocell beams. We also monitored the activities of the rats illuminated with two 36-watt overhead fluorescent tubes that had an intensity of 18-45 lx on the cage floors and 190-220 $1 \mathrm{x}$ in the center for 5 minutes (Sahin et al., 2016). The test apparatus was cleaned first with a wet and then dry napkin after the testing of each animal.

Statistical analysis: Statistical analysis of the results was made in SPSS for Windows (23.0.0; SPSS Inc., Chicago, IL, USA) package program. After testing the data for normal distribution, repeated measures Two-Way Analysis of Variance (ANOVA) was used to determine whether there were differences between the groups; and Post-Hoc Tukey HSD test was used to determine which group caused the difference. A p value $<0.05$ was taken to be statistically significant. 


\section{RESULTS}

The results were given as mean \pm standard deviation (SD). A significant difference was detected in the open field test performed in the first week of formaldehyde exposure between the control group and the groups exposed to FA in grooming and vertical movements $(\mathrm{p}<0.05)$ (Table I). It was found that the grooming and straightening movements were less in rats exposed to both low-dose and high-dose FA compared to the control group. When the tests done at the beginning and at the end of the experiment were compared, although a decrease was detected in the number of grooming and wandering in the control group, no differences could be detected between the groups in interand intra-group comparisons ( $p>0.05)$.

No differences were detected in the number of wandered frames and defecations that we looked at, in the open field test, between the groups and the tests performed at the beginning and end of the experiment.(p > 0.05) (Table II).

Table I. Number of grooming and vertical movements of experimental animals in the first and last weeks.

\begin{tabular}{llllr}
\hline & \multicolumn{2}{c}{ Number of grooming $($ mean \pm SD) } & Number of vertical movements (mean \pm SD) \\
\cline { 2 - 5 } & First week & Last week & First week & Last week \\
\hline CG $^{\mathrm{a}}$ & $1087.83 \pm 152.04 *_{\mathrm{b}^{\mathrm{c}}}^{\mathrm{c}}$ & $362.83 \pm 134.18$ & $381.83 \pm 59.95$ & $5.50 \pm 4.59$ \\
$\mathrm{LDGb}$ & $606.63 \pm 98.62$ & $341.13 \pm 89.38$ & $13.75 \pm 2.87$ & $4.75 \pm 3.28$ \\
$\mathrm{HDGc}$ & $588.63 \pm 161.69$ & $389.88 \pm 149.86$ & $11.63 \pm 6.14$ & $5.00 \pm 3.70$ \\
\hline$*: \mathrm{p}<0,05$ & & &
\end{tabular}

Table II. Number of defecation and horizontal movements of experimental animals in the first and last weeks.

\begin{tabular}{lllll}
\hline & \multicolumn{2}{c}{ Number of defecations (mean \pm SD) } & \multicolumn{2}{c}{ Number of horizontal movements (mean \pm SD) } \\
\cline { 2 - 5 } & \multicolumn{1}{c}{ First week } & Last week & First week & Last week \\
\hline CG & $4.0 \pm 3.85$ & $3.17 \pm 0.98$ & $837.50 \pm 345.95$ & $545.33 \pm 250.54$ \\
LDG & $2.63 \pm 2.20$ & $4.75 \pm 2.87$ & $1032.25 \pm 214.04$ & $490.00 \pm 197.49$ \\
HDG & $6.00 \pm 3.55$ & $6.13 \pm 2.70$ & $1006.38 \pm 390.07$ & $557.38 \pm 284.45$ \\
\hline
\end{tabular}

\section{DISCUSSION}

It was observed in our study that exposure to subchronic FA had negative effects on the behavior of rats, regardless of dose. However, there were no differences in the number of defecations and horizontal movements.

We can interpret the decreased straightening movements of rats because of FA as decreased curiosity about the environment (Küçük \& Gölgeli). Malek et al. (2004) obtained similar results in their study conducted on mice, and reported that FA exposure had long-term behavioral effects.

Malek et al. (2003a) subjected female rats to different doses of FA in the open field test twice, 2 hours and 24 hours after exposure. At the end of the first test, the grooming movements decreased, and the vertical movements decreased after the second test in the $1 \mathrm{ppm}$ group 2. However, they also reported that verticalmovements increased in the 5 ppm group. Similarly, they also observed an increase in the number of defecations compared to their first test in the second test of female rats in the $2.5 \mathrm{ppm}$ group. In a similar experiment by the same study group with rats, they observed decreased vertical movements in the first open field test done to mice exposed to FA, but they also reported that there was decreased vertical movements and increased grooming movements in the second test. They hypothesized that the decreased vertical movements in the first test may be because of increased anxiety. In our study, decreased number of grooming and vertical movements were detected in the groups that received FA compared to the control group. The open field test is frequently used in rodents, anxiety, rewarddependency studies, and some memory experiments in the form of repeated applications, and can evaluate locomotor activities (Karson et al., 2008). The open field test is one of the most popular ethological tests in evaluating anxietylike behavior in rodents (Kuniishi et al., 2017). However, it is argued that the same researchers obtained contradictory results in their studies conducted at different times. It is considered that this may have resulted from methodological differences or the prolonged effects of other tests before the open field test (Karson et al.). 
In a previous study, rats were exposed to different doses of FA for 90 days, and were subjected to the maze test to examine memory and behaviors. They reported that FA exposure caused long-term memory and behavior changes in rats (Pitten et al., 2000).

We can interpret the decrease in vertical movements and grooming numbers of rats exposed to FA In our study as a result of FA inhalation stressing the rats. Also, as we mentioned in our previous study, we can also argue that impaired brain function because of neurotoxicity also has an effect on behaviors (Tasdemir, 2019).

In their study, Finn et al. (2007) administered different FA doses to rats intraperitoneally in their study, and subjected the animals to the open field test. They reported that there were dose-dependent significant decreases in vertical movements, total displacement, grooming and defecation in FA-treated rats in the open field test. Although Malek et al. (2004), reported that the number of defecations increased in rats exposed to FA, Whimbey \& Denenberg (1967) reported that defecation and open field testing were two independent dimensions. We obtained different results in our study compared to previous studies, and we did not find significant differences in the number of defecations and horizontal movements of rats in the open field test.

Interestingly, although there were no significant differences in our study in locomotor activity parameters in the control group, we detected decreases in the second open field test. We believe that the 3-month period between the first test and the second test will mean a long time for the rats as they begin to age; and for this reason, it may cause changes in animal behaviors. As a matter of fact, it was reported in various studies that locomotor activity decreased with aging in healthy rats (Moinard $e t$ al., 2017; Szentes et al., 2019).

As a conclusion, FA caused behavioral changes in rats independent of dose and time. Based on our previous studies, we can speculate that this change might also have occurred because of the toxic effect on the central nervous system. We believe that more comprehensive and multidisciplinary studies are required to understand the full effect of FA on anxiety, memory and behaviors. We, as anatomists, are also in danger, neurologically and psychologically, because we have to be in very close contact with FA. As we cannot move FA away from the anatomy or medical sciences, we believe that people who are exposed or the relevant institutions must take necessary precautions in this respect.
TASDEMIR, R. \& COLAK, T. Evaluación de la exposicıón al formaldehído subcrónico en ratas con prueba de campo abierto. Int. J. Morphol., 39(6):1758-1762, 2021.

RESUMEN: El formaldehído (FA), una sustancia química indispensable en la anatomía y patología, pero es un elemento sumamente nocivo para todos los seres vivos., El objetivo de nuestro estudio fue investigar los cambios en el comportamiento de ratas expuestas a formaldehído subcrónico con prueba de campo abierto. Utilizamos 24 ratas Wistar-Albino divididas en 3 grupos. El primer grupo $(n=8)$ se identificó como el grupo de control y se aseguró una respiración normal de aire. En el segundo grupo se inhalaron dosis bajas de FA (media de $1 \mathrm{ppm}$ ) y en el tercer grupo se inhalaron dosis altas de FA (media de 10 ppm). La exposición a FA se realizó durante 4 horas, 12 semanas y 5 días a la semana. Las ratas fueron sometidas a una prueba de campo abierto durante la primera semana y la última semana de exposición a FA. Observamos disminuciones significativas en el número de movimientos verticales y acicalamiento en ratas en el grupo experimental en comparación con el grupo control en la prueba de campo abierto ( $\mathrm{p}<0.05)$. No se observaron diferencias significativas en los movimientos horizontales y el recuento de defecaciones ( $p>0,05)$. Como conclusión, podemos argumentar que la AF provoca cambios en el comportamiento de las ratas independientemente de la dosis y la duración.

PALABRAS CLAVE: Exposición al formaldehído; Prueba de campo abierto; Rata.

\section{REFERENCES}

Acar, E.; Tasdemir, R.; Hunc, F.; Colak, T.; Ozsoy, O. D.; Bamac, B. \& Kır, H. M. Investigation of the effect of formaldehyde inhalation on TXNIP and NF-KB levels in rat kidney. J. Anim. Plant Sci., 31(3):708-18, 2021.

Boja, J. W.; Nielsen, J. A.; Foldvary, E. \& Truitt Jr., E. B. Acute low-level formaldehyde behavioural and neurochemical toxicity in the rat. Prog. Neuropsychopharmacol. Biol. Psychiatry, 9(5-6):671-4, 1985.

Finn, D. P.; Fone, K .C.; Beckett, S. R.; Baxter, J. A.; Ansell, L.; Marsden, C. A. \& Chapman, V. The effects of pharmacological blockade of the 5HT(6) receptor on formalin-evoked nociceptive behaviour, locomotor activity and hypothalamo-pituitary-adrenal axis activity in rats. Eur. $J$. Pharmacol., 569(1-2):59-63, 2007.

Ge, S.; Yan, B.; Huang, J.; Chen, Y.; Chen, M.; Yang, X.; Wu, Y.; Shen, D. \& Ma, P. Diisodecyl phthalate aggravates the formaldehyde-exposureinduced learning and memory impairment in mice. Food Chem. Toxicol., 126:152-61, 2019.

Karson, A.; Onat, F.; Balc1, F. \& Ates, N. Locotomor activity, leaming and memory in VVAG/Rij rats with absence epilepsy. Epilepsi, 14(3):167$75,2008$.

Katsnelson, B. A.; Degtyareva, T. D.; PrivalovaIlzira, L. I.; Minigaliyeva, I. A.; Slyshkina, T.; Ryzhov, V. V. Yu, O.; Beresneva. Attenuation of subchronic formaldehyde inhalation toxicity with oral administration of glutamate, glycine and methionine. Toxicol. Lett., 220(2):181-6, 2013.

Kuniishi, H.; Ichisaka, S.; Yamamoto, M.; Ikubo, N.; Matsuda, S.; Futora, E.; Harada, R.; Ishihara, K. \& Hata, Y. Early deprivation increases highleaning behavior, a novel anxiety-like behavior, in the open field test in rats. Neurosci. Res., 123:27-35, 2017.

Küçük, A. \& Gölgeli, A. Deney hayvanlarında anksiyete modelleri ve anksiyetenin deg erlendirilmesi. Sag lık Bilimleri Dergisi, 14 (3):209$17,2005$. 
Li, F.; Yujie, Qin.; Gong, S.; Zhang, H. \& Ding, S. Learning and memory impairment of mice caused by gaseous formaldehyde. Environ. Res., 184:109318, 2020.

Liu, Y.; Ye. Z.; Luo, H.; Sun, M.; Li, M.; Fan, D. \& Chui, D. Inhalative formaldehyde exposure enhances aggressive behavior and disturbs monoamines in frontal cortex synaptosome of male rats. Neurosci. Lett., 464(2):113-6, 2009.

Malek, F. A.; Möritz, K. U. \& Fanghänel, J. A study on specific behavioral effects of formaldehyde in the rat. J. Exp. Anim. Sci., 42(3):160-70, 2003b.

Malek, F. A.; Möritz, K. U. \& Fanghänel, J. Effects of a single inhalative exposure to formaldehyde on the open field behavior of mice. Int. J. Hyg. Environ. Health, 207(2):151-8, 2004.

Malek, F. A.; Möritz, K. U. \& Fanghänel, J. Formaldehyde inhalation \& open field behaviour in rats. Indian J. Med. Res., 118:90-6, 2003 a.

Matsuoka, T.; Takaki, A.; Ohtaki, H. \& Shioda, S. Early changes to oxidative stress levels following exposure to formaldehyde in ICR mice. $J$. Toxicol. Sci., 35(5):721-30, 2010.

Moinard, C.; Tliba, L.; Diaz, J.; Le Plénier, S.; Nay, L.; Neveux, N.; Cynober L. \& Raynaud-Simon, A. Citrulline stimulates locomotor activity in aged rats: Implication of the dopaminergic pathway. Nutrition, 38:912, 2017.

Organization For Economic Cooperation And Development (OECD). Screening Information Data Set, 2009.

Pitten, F. A.; Kramer, A.; Herrmann, K.; Bremer, J. \& Koch, S. Formaldehyde neurotoxicity in animal experiments. Pathol. Res. Pract., 196(3):193-8, 2000

Prut, I. \& Belzung, C. The open field as a paradigm to measure the effects of drugs on anxiety-like behaviors: a review. Eur. J. Pharmacol., 463:333, 2003.

Sahin, D.; Erdolu, C.O.; Karadenizli, S.; Kara, A.; Bayrak, G.; Beyaz, S.; Demir, B. \& Ates, N. Effects of gestational and lactational exposure to low dose mercury chloride $(\mathrm{HgCl} 2)$ on behaviour, learning and hearing thresholds in WAG/Rij rats. EXCLI J., 15:391-402, 2016.

Szentes, N.; Tékus, V.; Mohos, V.; Borgély, É. \& Helyes, Z. Exploratory and locomotor activity, learning and memory functions in somatostatin receptor subtype 4 gene-deficient mice in relation to aging and sex. GeroScience, 41(5):631-41, 2019.

Tasdemir, R. Morphological and bihemical analysis of the effect of formaldehyde inhalation on nervous system in ratsoc. $\mathrm{PhD}$ Thesis, Kocaeli, 2019.

Whimbey, A. E. \& Denenberg, V. H .Two independent behavioral dimensions in open field performance. J. Comp. Physiol. Psychol., 63(3):500-4, 1967.

Zhang, Y.; Yang, Y.; He, X.; Yang, P.; Zong, T.; Sun, P.; Sun, R. C.; Yu, T. \& Jiang, Z. The cellular function and molecular mechanism of formaldehyde in cardiovascular disease and heart development. J. Cell. Mol. Med., 25(12):5358-71, 2021.

\author{
Corresponding author: \\ Rabia Tasdemir \\ Department of Anatomy \\ Faculty of Medicine \\ Gaziantep Islam Science and Tecnology University \\ Gaziantep \\ TURKEY
}

\section{E-mail: rabiatsdmr@gmail.com}

Received: 01-07-2021

Accepted: 27-09-2021 